\title{
Enduring consensus: why the EU legislative process stays the same
}

\section{Stéphanie Novak, Olivier Rozenberg \& Selma Bendjaballah}

To cite this article: Stéphanie Novak , Olivier Rozenberg \& Selma Bendjaballah (2020): Enduring consensus: why the EU legislative process stays the same, Journal of European Integration, DOI: 10.1080/07036337.2020.1800679

To link to this article: https://doi.org/10.1080/07036337.2020.1800679

曲 Published online: 07 Aug 2020.

Submit your article to this journal $\asymp$

山 Article views: 72

Q View related articles $\asymp$

View Crossmark data $\nearrow$ 


\title{
Enduring consensus: why the EU legislative process stays the same
}

\author{
Stéphanie Novak (10) ${ }^{\mathrm{a}}$, Olivier Rozenberg $\mathbb{1}^{\mathrm{b}}$ and Selma Bendjaballah ${ }^{\mathrm{c}}$
}

'Department of Linguistics and Comparative Cultural Studies, Ca' Foscari University of Venice, Venice, Italy; ${ }^{b}$ Centre d'études Européennes et de Politique Comparée, Sciences Po, Paris, France; 'Centre de Données

Socio-politiques, Sciences Po, Paris, France

\begin{abstract}
The multiple crises that the EU has faced over the last decade could lead observers to expect an increase in conflicts within its legislative process and, eventually, a shift from a consensual mode to a majoritarian and politicized mode. The dataset The EU Legislative Output 1996-2019 indicates that this has occurred only to a moderate extent. To explore this enduring consensus, we analyse quantitative and qualitative data on law making within the Council of the EU and the European Parliament and proceed to a systematic diachronic comparison. We argue that, as before the crisis, consensus remains a norm and results from cooperation based strategies. Furthermore, new factors, such as the extension of the ordinary legislative procedure, a pro-EU alliance within the European Parliament and the smaller number of legislative proposals, foster consensus.
\end{abstract}

\section{KEYWORDS}

EU institutions; consensus; compromise; EU legislative process

\section{Introduction}

Consensus has been considered a cornerstone of the EU's political process for many years (Dehousse 1995; Elgström and Jönsson 2000; Costa and Magnette 2003; Hix 2014). It is characteristic of intergovernmental deliberation in the European Council (Puetter 2014), as well as the legislative process in the Council of the EU (Lewis 2003; Hayes-Renshaw, Van Aken, and Wallace 2006) and in the European Parliament (EP) (Kreppel and Tsebelis 1999; Settembri and Neuhold 2009; Burns 2013). However, recent studies (Fabbrini 2016; Magone, Laffan, and Schweiger 2016; Dinan, Nugent, and Paterson 2017) could indicate that this famous spirit of consensus is no longer present at the EU level. In particular, the Great Recession (2008-2012) strengthened the economic and diplomatic gaps between Northern and Southern Europe. In addition, the 'Visegrad group' (Czech Republic, Hungary, Poland and Slovakia) tends to keep to itself (Wurzel, Liefferink, and Di Lullo 2019, 261-262), and anti-EU parties achieved victories during the 2014 and 2019 EP elections. In most member states, including the biggest ones, populist parties have gained ground during the 2010s, framing a large part of their platform on disparaging the EU (Noury and Roland 2020; Treib 2020).

CONTACT Stéphanie Novak stephanie.novak@unive.it E Ca' Foscari University of Venice, Ca' Bernardo, Venice 30123, Italy

@ 2020 Informa UK Limited, trading as Taylor \& Francis Group 
The polycrisis (Juncker 2016) as well as the constraining dissensus (Hooghe and Marks 2009) that comprises the greater saliency and politicisation of EU issues (De Wilde and Zürn 2012; Börzel and Risse 2018; Zeitlin, Nicoli, and Laffan 2019), could make legislative compromise less likely. However, we contend that, given the long-term trends, the search for consensus remains remarkably enduring within the Council and the EP. Although recent studies of the legislative process have focussed on the role of trilogues in the elaboration of interinstitutional compromises (see for instance Reh et al. 2013; RoedererRynning and Greenwood 2015; Brandsma 2018), we focus on intrainstitutional consensus in both legislative institutions. To our knowledge, existing studies have not investigated or compared the reasons for consensus in the Council and in the EP from a diachronic perspective. We adopt an original longitudinal approach to discuss whether this unexpectedly enduring consensus results from factors that contributed to consensus before the crisis, from new factors or from both. Factors that existed before the crisis centre on two theoretical claims: first, that consensus is a constraining social norm of behaviour, and second, that it is in the rational interest of legislative actors to compromise. In addition, we identify three factors resulting from the changing situation: the generalization of the ordinary legislative procedure (OLP) with the Lisbon Treaty, the fact that the Commission makes fewer legislative proposals and the fact that the dynamism of anti-EU forces may push other actors to form alliances. We discuss these different and nonmutually exclusive explanations using a variety of data: mostly interviews realised within the Council and the EP before 2009 and during the 2010s, but also a dataset on the legislative procedure, The EU Legislative Output 1996-2019 ${ }^{1}$. We argue that the conjunction of social pressure, rational strategies, institutional constraints and (paradoxically) the emergence of anti-EU forces in the EP explains the enduring consensus in EU legislative institutions.

The second section of the paper presents the general trends related to voting patterns in the Council and the EP and establishes the continuity of the consensual features. The third section develops five articulated hypotheses aimed at explaining this stability. The fourth section presents our methodology and data. The fifth section assesses our hypotheses in light of our data.

\section{An enduring consensus}

Although existing studies note a tendency to consensus in both legislative institutions, consensus in the Council refers to the high proportion of decisions made without explicit voting (Hayes-Renshaw, Van Aken, and Wallace 2006), whereas, in the EP, consensus refers to the fact that legislative acts are adopted by broad majorities (Kreppel 1999; Lord 2003). Furthermore, as we discuss in section 3, the sociological institutionalist and the rationalist perspectives enrich our understanding of consensus in legislative institutions.

One can assess the evolution of consensus by checking the support for the final version of the bills within each legislative institution. We use our dataset The EU Legislative Output 1996-2019, which includes all EU bills adopted between 1996 and 2019². Each act is related to 100 connected variables that deal with descriptive elements related to the bills, such as their size or the policy field, as well as behavioural elements related to the 
legislative process, such as the duration or the votes within EU institutions. Our data show that the rate of opposition to adopted legislative acts remains relatively low.

In the case of the Council, we take into account acts for which qualified majority voting (QMV) was the decision rule because they represent $79 \%$ of the legislative acts adopted from 2004 to 2009 and more than 90\% of the legislative acts adopted since 2004 . Abstention must be considered a form of opposition because, when the rule is QMV, abstaining amounts to voting against the act. Figure 1 presents the proportion of acts for which there was at least one opposition or one abstention by a given member state, as well as the same data excluding legislative acts that were contested only by the UK.

The data shown in Figure 1 reveal that, in spite of the polycrisis, contestation has remained relatively low, although legislative acts were more frequently contested in 2018 and 2019 , with contestation rates of $43 \%$ and $47.5 \%$ respectively. However, these increases should be relativised, as they were partly caused by increases in the proportion of acts for which only one member state abstained or expressed opposition ( $21 \%$ in 2018 and 30\% in 2019, see Figure 5). Moreover, if we exclude the acts that appear contested only because the UK abstained or opposed them (Figure 1), the level of contestation in 2018 and 2019 does not appear so unusually high (35\% in 2018 and 28\% in 2019). In 2019, 20\% of adopted acts appear to be contested only because the UK abstained. Accordingly, the recent increase in contestation appears very much linked to the Brexit context that led the UK to cast isolated abstentions.

The same kind of data can be considered regarding the final votes on the definitive version of the EU bills in the EP. ${ }^{3}$ The overall picture is one of a persistent tendency to adopt acts with a broad majority despite the opposition or abstention of a small number of members of the EP (MEPs) and groups. Figure 2 shows the percentage of MEPs' votes in favour of and against each proposal voted on floor from 2004 to 2019.

Our data reveal a highly stable picture. The percentage of MEPs who voted in favour of the proposals increased from $65 \%$ in 2005 to $79 \%$ in 2016 . The lowest percentage is to be found in 2005, four years before the financial crisis hit the EU. On average, every year,

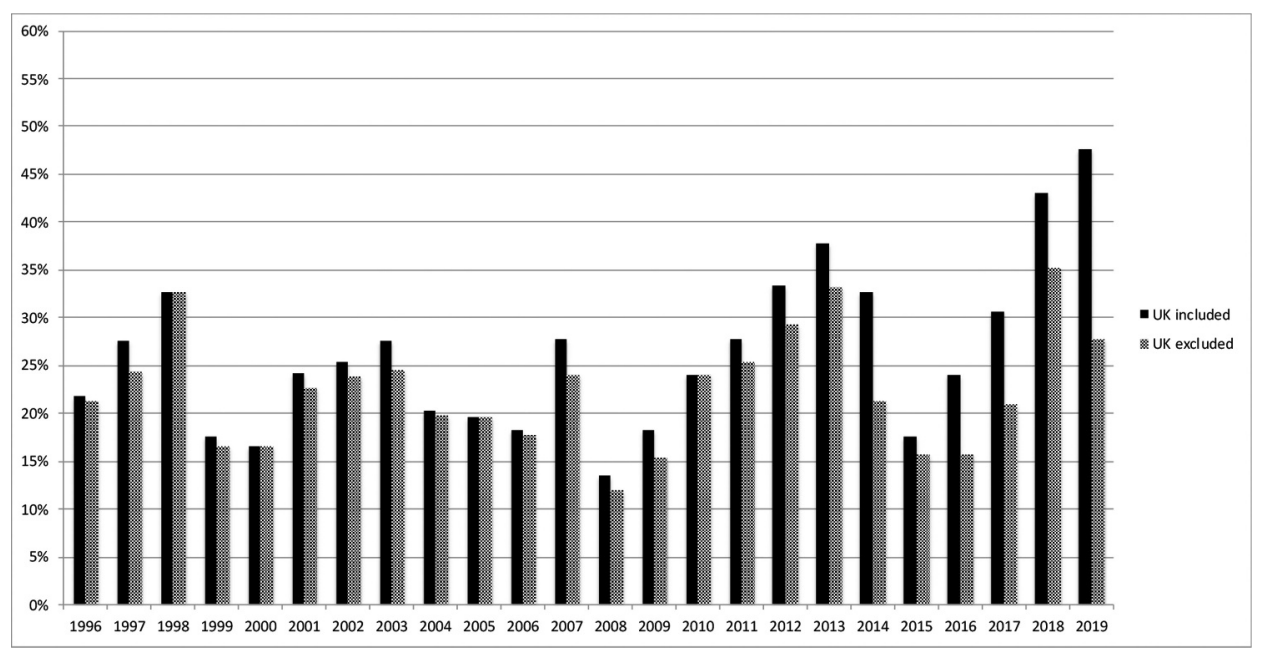

Figure 1. Percentage of contested acts, Council of the EU, 1996-2019. 


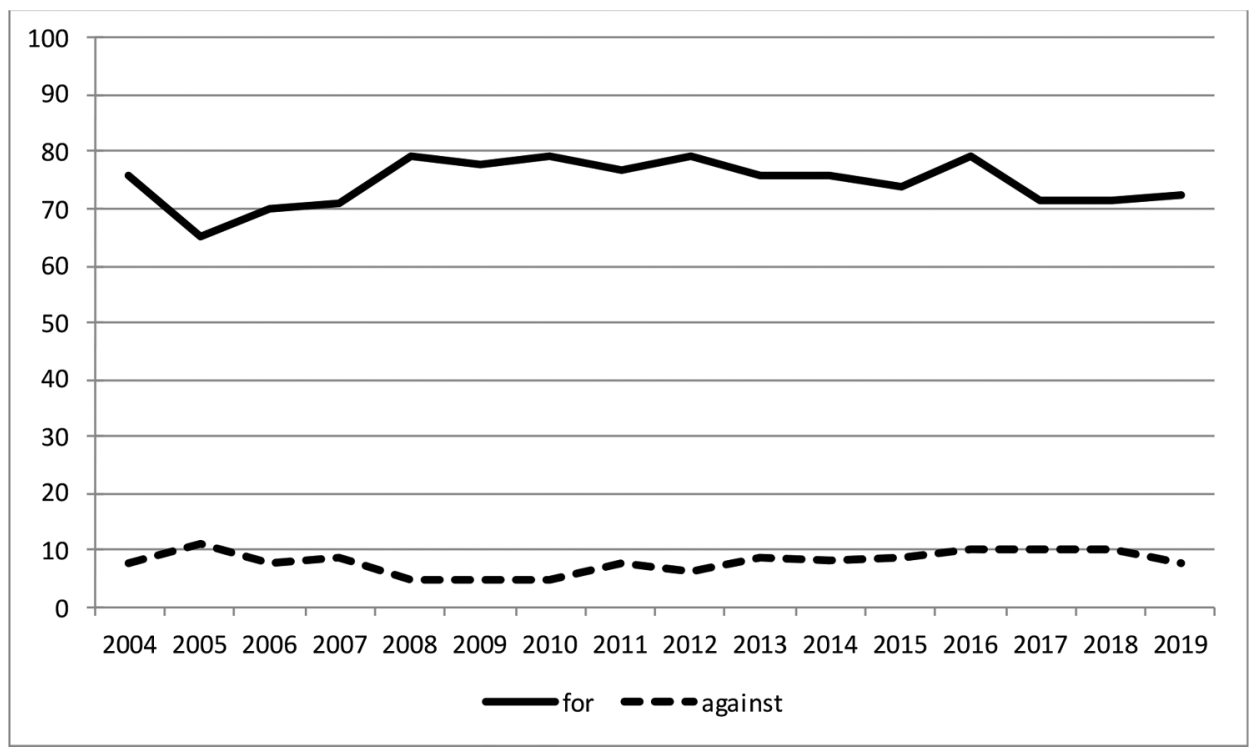

Figure 2. Votes in the EP (\%), 2004-2019.

fewer than 50 MEPs opposed adopted acts, and this number remained stable throughout the period. Thus, the extent of consensus in the EP appears to be even greater than in the Council.

\section{An explanatory framework}

In this section, we present five non-mutually exclusive hypotheses to explain the consensus within EU legislative bodies. The first two hypotheses imply that the logic that worked before greater tensions emerged remains relevant. The three additional hypotheses are specific to the post-2009 period.

\section{Norm continuity}

The first explanation is based on the sociological institutionalist view that actors do not easily modify their behaviours and follow norms that are deeply rooted in the social context (Johnston 2001). The norm of consensus, which is based on a variety of practices, constrains their behaviour even when the incentives not to cooperate are stronger (Laffan 2004; Thomas 2009, 347-348). According to this hypothesis, the rise of economic threats or of Eurosceptic actors is not sufficient to break the norm of consensus within institutions.

Accordingly, we expect consensus to be a 'reflex' (Lewis 2003, 1007) among Council members and to depend upon a logic of appropriateness (Lewis 2005). The presidency would encourage delegations to join the majority and refrain from outvoting them in the open. Representatives would avoid threatening to vote against measures and join the consensus because they do not want their peers to perceive them as isolated. 
MEPs would identify consensus-building as a sort of institutional mission(Ripoll Servent 2018)and as a way to assert their identity as normal legislators, which associates consensus with responsibility (Roederer-Rynning and Greenwood 2015; Bressanelli and Chelotti 2018, 79). In a context in which the Lisbon Treaty has empowered the EP, we expect MEPs to face strong incentives to show that they use their new powers responsibly and constructively.

\section{Utilitarian strategies}

According to the second hypothesis, maximisation strategies explain why ministers and MEPs often vote in favour of legislative proposals: actors prioritise their views on the EU's legislative agenda and fight only for what is centrally important to them. They go along with their peers regarding issues they consider non-strategic and expect this cooperative behaviour to be reciprocated when addressing the issues they really care about. Existing studies argue that Council members use logrolling (Mattila and Lane 2001) and issue linkage (McKibben 2010, 700; König and Junge 2011) to avoid being outvoted. Accordingly, we expect the shadow of the vote to foster cooperation among representatives.

Moreover, repeated interactions within both institutions constitute a strong incentive for cooperation. This favours a process of temporal logrolling (Mühlböck and Rittberger 2015) in which actors can expect that their cooperative attitudes will be paid for in the future by decisive support from other actors. Furthermore, MEPs commonly seek consensus because it helps them advance their careers within the institution (Hix et al. 2007; Whitaker 2011; Yordanova 2013). For instance, it is in the interest of rapporteurs to strike deals, as their reputations depend on their ability to consolidate differing opinions (Benedetto 2005). For backbenchers, participating in compromise-building may be a way to balance the power of the rapporteur and gain influence (Brandsma 2018). Accordingly, we expect the shadow of the future to influence the actors' strategies.

\section{The generalization of the OLP}

According to this third view, the resilience of consensus in EU legislative institutions results from the generalization of the OLP with the Lisbon Treaty, which makes the degree of agreement within each institution crucial. According to our data, 57\% of acts were not adopted using the co-decision procedure during the first term of President Barroso (2004-09). This was the case for only $16 \%$ of acts during his second term (2009-14) and less than 10\% during President Juncker's mandate (2014-2019). This represents a huge shift in favour of the EP. Plausibly, this trend gives greater value to each legislative body's capacity for internal agreement. As indicated by congressional scholars (Krehbiel 1998), the bicameral feature of a given political system strengthens the strategic advantage of obtaining large majorities within each assembly. In the bicameral bargains, large majorities serve as signals of the level of cohesiveness and determination of each actor. For instance, Kreppel stresses the importance of parliamentary unity in enabling the EP to amend legislation (Kreppel 1999; see also Burns 2013, 1000). Accordingly, we expect interviewees from both institutions to refer to the influence of their co-legislators and to express institutional patriotism. 


\section{Number of legislative proposals}

The post-2009 period has seen the emergence of another type of institutional constraint: the European Commission issues fewer proposals. This institution has become less collegial (Kassim et al. 2017), and the increased internal leadership of its President has placed him in a position to block some legislative proposals from its services more easily than before. Legislative drafts could have been filtered to avoid matters of conflict. Accordingly, we expect our interviewees to refer to the number of legislative proposals they negotiated.

\section{Pro-EU alliance}

The last factor that accounts for the enduring consensus derives from the context of the tension itself. Increased divisions between EU actors could make it even more necessary to exert patient and collective efforts to seek for a consensus among those willing to play the functionalist game. The rise of Eurosceptic ministers or MEPs would constitute a strong incentive for other actors to form alliances. Independently of EU politics, the rise of Eurosceptic and populist forces at the domestic level would also push traditional forces to cooperate and even to cartelize (Katz and Mair 1995). The frequency with which large left-right coalitions formed during the recent period, especially in Germany's case, could also contributed to this trend. Greater proximity between mainstream political forces at the domestic level would, as a result, facilitate their bargains at the EU level. Accordingly, we expect our data to reveal the convergent votes of pro-EU forces, and we expect our interviewees to refer to the cleavage between anti-EU and pro-EU groups.

We do not propose to test these five explanations as alternative hypotheses, as they appear largely reconcilable and may even strengthen each other. Rather, we are interested in identifying whether the two sociological and rational-choice justifications for consensus still hold during the recent period and/or if other explanations are now more relevant.

\section{Data and methodology}

For this research, we relied on two kinds of evidence. First, we used our dataset The Legislative Output in the European Union 1996-2019 (see section 2). Second, we interviewed EU officials, MEPs and members of national permanent representations. To assess the stability of the decisional practices and test our various hypotheses, we approach our 99 interviews longitudinally by mainly comparing two sets of interviews over time. The first one was completed in 2007-2008, just before the economic crisis and the change in institutional rules resulting from the Lisbon Treaty. Six interviews were carried out in the middle of the crisis in 2012. The second wave took place from 2016 to 2019, ten years after the Great Recession's official start. Appendix 2 contains further information about our 99 interviews $^{4}$ and our methodology. In section 5, we discuss each hypothesis and present extracts from interviews to provide evidence of the similarity of descriptions and justifications given by the actors over the period (Table 1 through 5). 
Table 1. The norm of consensus in the Council.

\begin{tabular}{|c|c|c|}
\hline & 2007-2008 & 2012-2018 \\
\hline $\begin{array}{l}\text { The presidency } \\
\text { compromise }\end{array}$ & $\begin{array}{l}\text { A presidency always seeks a large majority to } \\
\text { avoid too much bitterness. (I-2007-1) }\end{array}$ & $\begin{array}{l}\text { The role of the presidency in seeking } \\
\text { compromise is central. They are supposed to } \\
\text { be neutral, which helps them to find } \\
\text { a compromise. (I-2018-2) }\end{array}$ \\
\hline $\begin{array}{l}\text { Avoiding isolation } \\
\text { and joining the } \\
\text { consensus }\end{array}$ & $\begin{array}{l}\text { The presidency seeks consensus and ends up } \\
\text { saying: 'I try to please everyone but I stop } \\
\text { here'. Those who had been opposed then join } \\
\text { the majority as they don't want to appear as } \\
\text { losers. (I-2007-1) } \\
\text { In the Council, it is frequent that if some } \\
\text { members states give up and adhere to the } \\
\text { proposal, it influences others who were also } \\
\text { against. A member state doesn't want to } \\
\text { appear isolated. (I-2008-1) }\end{array}$ & $\begin{array}{l}\text { Currently we are against the mobility package. } \\
\text { Still, we are not going to block an agreement. } \\
\text { (I-2018-1) } \\
\text { The presidency knows if it has a majority or } \\
\text { not. It avoids voting not to expose those who } \\
\text { are opposed. Instead of the vote, the } \\
\text { presidency notes that there is a qualified } \\
\text { majority. (I-2012-1) }\end{array}$ \\
\hline
\end{tabular}

\section{Findings}

\section{Consensus as a norm}

According to the first hypothesis, consensus is a behavioural norm that can constrain actors. The recent context of greater saliency in EU issues and tensions between EU actors therefore provides a unique opportunity to test a norm's resistance to external shocks, which is an issue central to sociological institutionalism.

Our interviews with Council members (see Table 1) indicate that, to some extent, consensus remains a norm in the Council even if some member states occasionally violate it (particularly the UK, members of the Visegrad group and Germany, as noted by an official of the Council General Secretariat [1-2016-1] and as confirmed by our data[see 'A pro-EU alliance' below]). The presidency appears to be the main actor of such continuity. In 2008, just as ten years later, reaching a consensus within the Council was considered a sign of the presidency's success. The art of the presidency consists of finding a balance between building a compromise and pointing to the risk of isolation a given member state faces if it does not join the majority. The fear of ostracisation of the various partners appears to be a central element of the compromise-building mechanism that pushes some opponents to join the majority if they are isolated. To comply with the norm of consensus, the presidency used some procedural tactics throughout the period. For instance, it announced that a political agreement had been reached in order to push some pivotal players to support it. It also usually asked opponents and abstainers to speak up - giving an implicit advantage to those forming the majority and increasing the cost of explicit opposition.

In addition, a share of MEPs from Eurosceptic groups often decided to support the final outcome. During the period 2009-2014, when the right-wing Eurosceptic or Europhobe MEPs represented about $15 \%$ of the seats of the assembly and the radical left represented $5 \%$, yearly opposition to the final versions of EU bills was between 4 and $8 \%$ of the seats, depending on the year. This indicates that part of the anti-EU forces decided to compromise. During the 2014-2019 legislature, right-wing Eurosceptic or Europhobe MEPs represented about one seat out of five, and the radical left group represented $7 \%$. Yearly opposition to the final versions of EU bills was slightly higher than during the previous legislature (around 10\%), but it remained far below what those groups' weights 
would have led us to expect. Those figures can partly be explained by the fact that those groups showed the lowest rate of cohesion among EP groups despite their smaller sizes (Hix et al. 2007).Some members progressively decided to play the institutional game by amending proposals and sometimes supporting their final versions. Arguably, the reasons for those shifts are complex. The literature suggests that the dominant norm of compromise pushes some initially radical MEPs to adopt a more pragmatic attitude (Brack 2018; Ripoll Servent and Panning 2019). The following account by a liberal MEP provides us with an illustration of such process:

We had Mrs X from the National Front. She left and became more pro-EU than others. Now she is pro-EU - approving everything. We turned her. [...] We made visits, we travelled by car, with some colleagues and assistants. She was treated like others. And the French judge invited her for lunch. In the end she said: 'I don't care about my group, I am gonna vote with you guys'(I-2017-1).

Interviews of members belonging to pro-EU groups provide ample evidence of the strength of the norm of consensus among their members. This norm appears to be closely linked to the definition of the institution as an open one. MEPs emphasize their greater ability to collaborate compared to the Council, given their distance from national interests. When comparing themselves to national parliaments, they also stress the greater fluidity of the internal cleavages. As shown in Table 2, interviews conducted with MEPs in 2008 and 2018 were remarkably convergent. As it is the case for the Council, the strength of the norm of compromise can be perceived through its effect on MEPs' personal reputations. An MEP who is able to convince colleagues of a given proposal is perceived more positively, which confirms that there is indeed a social pressure to compromise.

\section{Rational strategies}

Furthermore, voting with the majority can be considered an individual calculus. In the Council and in the EP, actors often acknowledge that it is in their interests to join or remain with the majority. The continuity of the views expressed by member states' representatives before and after 2009, as well as those of MEPs, is striking.

Table 2. The norm of consensus in the EP.

\begin{tabular}{|c|c|c|}
\hline & 2007-2008 & 2018 \\
\hline An old habit & $\begin{array}{l}\text { The Parliament is an institution that has } \\
\text { always had the habit of compromise, and } \\
\text { because it is not organised as a majority } \\
\text { versus a minority, and is less nationalist } \\
\text { than the Council, we regularly make } \\
\text { decisions along political lines, in political } \\
\text { groups, and, in the end, it is relatively } \\
\text { easy to get to a majority. (I-2008-2) }\end{array}$ & $\begin{array}{l}\text { I am not at all surprised by those huge } \\
\text { majorities. That's the way it works in } \\
\text { parliament. We have to build huge } \\
\text { majorities for each and every dossier. } \\
\text { A common position cannot be imposed } \\
\text { beforehand as in national parliaments. } \\
(\mathrm{I}-2018-4)\end{array}$ \\
\hline $\begin{array}{l}\text { Social pressure for } \\
\text { compromise }\end{array}$ & $\begin{array}{l}\text { What matters is the support you get for your } \\
\text { opinions, proposals or amendments. The } \\
\text { more support you get, the better. I don't } \\
\text { know exactly why this is the case, but } \\
\text { I have to admit that this is a rule. (I-2007-3) }\end{array}$ & $\begin{array}{l}\text { France has often been shamed as growth is } \\
\text { low and unemployment significant. } \\
\text { Therefore it is true that for a French MEP } \\
\text { as myself who plays a role in seeking } \\
\text { compromise the task is all the more } \\
\text { difficult. [...] If you want, I am still being } \\
\text { put to the test, although I've been an } \\
\text { MEP for several terms. (I-2018-5) }\end{array}$ \\
\hline
\end{tabular}


In 2007 and a decade later as well, Council negotiators anticipated that the presidency would seek to gather enough support to build a qualified majority and that it was therefore in their interests to be 'constructive' to avoid being outvoted. Furthermore, negotiators avoided adopting 'obstructionist' strategies because these could lead the presidency to overlook them in future negotiations. When delegations build a blocking minority against a given measure, they aim not to block its adoption altogether, but to receive concessions that will allow them to join the majority.

In addition to internal tactics, another aspect of the representatives' interest in joining the majority relates to public votes. Throughout the period, ministers chose to cast negative votes or abstentions to send signals to their constituents (Hayes-Renshaw, Van Aken, and Wallace 2006). However, in most cases, they did not want to show to the press and their constituents that they had been defeated because this entailed more costs than gains, both immediately and in future negotiations. Therefore, they sometimes decided to support the majority even though the political agreement reached was unsatisfactory for them. This general rule depended on the types of dossiers under consideration and on the member state, but we observed no variations on this key issue throughout the period.

A last aspect of the rationality of the decision to compromise in the Council regards the presidency. In 2008 and 2018, our interlocutors stressed that the rotating presidency constituted a strong incentive for playing the honest broker. The 'shadow of the future' in this case, the certainty that one will soon resume the status of an ordinary member pushes the presidency to accommodate member states when key national interests are at stake (see Table 3).

MEPs have a personal interest in participating in the majority. Their behaviours during the legislative procedure directly impact their reputation in the group and the whole assembly. Institutional resources within the EP, such as rapporteurship or chairpersonship, depend on a given MEP's reputation as a deal-maker. Therefore, MEPs from pro-EU groups

Table 3. Consensus and individual strategies in the Council.

\begin{tabular}{|c|c|c|}
\hline & $2007-2008$ & $2012-2018$ \\
\hline Shadow of the vote & $\begin{array}{l}\text { When the rule is QMV, one gives up. There is } \\
\text { no point in voting against. } \\
\text { With qualified majority, nobody wants to } \\
\text { be outvoted [...] it is a sword of Damocles } \\
(1-2007-1) \text {. }\end{array}$ & $\begin{array}{l}\text { When the rule is QMV [.... w]e know there } \\
\text { will be a compromise. (I-2018-3) }\end{array}$ \\
\hline $\begin{array}{l}\text { Cooperation and blocking } \\
\text { minority }\end{array}$ & $\begin{array}{l}\text { The aim of the working groups is to } \\
\text { aggregate a maximum of support for } \\
\text { your positions. From the working group, } \\
\text { you should adopt a tactic - not just say } \\
\text { your position. You should adapt to the } \\
\text { balance of power, join the qualified } \\
\text { majority if you cannot form a blocking } \\
\text { minority. (I-2007-4) }\end{array}$ & $\begin{array}{l}\text { My country [a medium-size country] will not } \\
\text { fight systematically when we disagree } \\
\text { with a text. We will rather seek to work } \\
\text { with big delegations that are well } \\
\text { considered by the presidency so that } \\
\text { some of our priorities would be } \\
\text { supported. (I-2018-1) }\end{array}$ \\
\hline Blame-avoidance & $\begin{array}{l}\text { Ministers don't have interest to show their } \\
\text { public opinion they voted against [...] We } \\
\text { opposed for instance on CAP issues and } \\
\text { the [domestic] opposition said that we } \\
\text { negotiated poorly. (I-2007-5) }\end{array}$ & $\begin{array}{l}\text { If a member state stands alone, it is not well- } \\
\text { perceived by the press. You should not } \\
\text { tilt at windmills. (I-2012-2) }\end{array}$ \\
\hline Shadow of the future & $\begin{array}{l}\text { A presidency should avoid putting too many } \\
\text { members in the minority as there is a risk } \\
\text { of retaliation afterwards. It is like in } \\
\text { a family: if you're hurt, you'll have } \\
\text { occasions to hurt later. (I-2008-1) }\end{array}$ & $\begin{array}{l}\text { This presidency made a lot not to outvote } \\
\text { member states. It is itself a member state! } \\
\text { [...] The presidency treated member } \\
\text { states as it wanted to be treated after the } \\
\text { presidency. (I-2018-6) }\end{array}$ \\
\hline
\end{tabular}


have a strong personal interest in compromising - be they office- or policy-seekers. As shown in Table 4, a hard-working reputation is not sufficient: members must also show pragmatism and openness to accepting responsibilities. The concrete daily work of participating in bargains and finding compromises is also a source of personal satisfaction for MEPs. Such gratification seems to derive both from their colleagues' recognition and their taste for engaging in those activities. In an extended version of rationality, such forms of gratification can be considered personal goals pursued through policy activities. Thus, the MEPs' decision to address their emotional expectations by cooperating with others is, in that sense, a rational strategy.

\section{The generalization of the OLP}

Having considered two explanations for the high level of consensus that already operated before the crisis, we now turn to the generalization of the OLP (Figure 3).

Interviews conducted in the EP in 2008 and 2018 (see Table 5) indicated that the institutional competition with the Council was a major source of consensus within the EP, which confirms an established result of the literature on that point (Burns 2013). Rapporteurs often seek to be widely supported by their colleagues to show the Council how determined the EP is. Participation in trilogues contributes to fostering internal compromises. Furthermore, institutional patriotism occasionally plays a role vis-à-vis the Commission - not just the Council.

Interviews conducted in the Council before 2009 indicated that the weight of the EP led Council members to present a unified face to their co-legislators. Ten years later, the EP was often present in the Council officials' discourses. In contrast to the EP, the institutional competition is not presented as a factor of internal cohesion but rather as a threat to it. Interlocutors stress that the Council's initial endeavours to identify a majority are developed without much consideration for the EP's position. It is only during the

Table 4. Consensus and individual strategies in the EP.

\begin{tabular}{|c|c|c|}
\hline & 2008 & 2018 \\
\hline Seeking responsibilities & $\begin{array}{l}\text { I've been here the whole time. I went to see } \\
\text { people one after the other. I made efforts. } \\
\text { I tried to hang on, to ask questions, to } \\
\text { show I was listening, available. And in the } \\
\text { end they gave me a rapport. I guess they } \\
\text { trusted me because I had been able to } \\
\text { show them I was available, highly } \\
\text { committed and respectful for the work. } \\
\text { (I-2008-4) }\end{array}$ & $\begin{array}{l}\text { I am rapporteur today because I've been } \\
\text { able to show I was not blocking texts. } \\
\text { Here, once you show your commitment } \\
\text { but also your collaborative state of } \\
\text { mind - because seeking compromises is } \\
\text { not an easy job... So, yes, I was saying, if } \\
\text { you work a lot, if you include everyone } \\
\text { even those who don't want, then, yes, } \\
\text { people trust you and give you } \\
\text { responsibilities. (I-2018-7) }\end{array}$ \\
\hline Seeking recognition & $\begin{array}{l}\text { [Finding compromise] is a lot of work. But it } \\
\text { is fascinating. It is important to say we've } \\
\text { been successful. Vis-à-vis my colleagues, } \\
\text { it shows we've been trusted, that we } \\
\text { have some qualities, that we are able to } \\
\text { work in-depth, that we are not afraid by } \\
\text { working. (I-2008-5) }\end{array}$ & $\begin{array}{l}\text { If you want to be recognized here, it is } \\
\text { important to show you're able to do that. } \\
\text { I would go further by saying: you should } \\
\text { show you like it. As for me, I've done that } \\
\text { with passion: finding compromises } \\
\text { between and even within delegations. If } \\
\text { I hadn't shown I like doing that, and if } \\
\text { I had failed, I would not be today vice- } \\
\text { chair of my group. (I-2018-8) }\end{array}$ \\
\hline
\end{tabular}




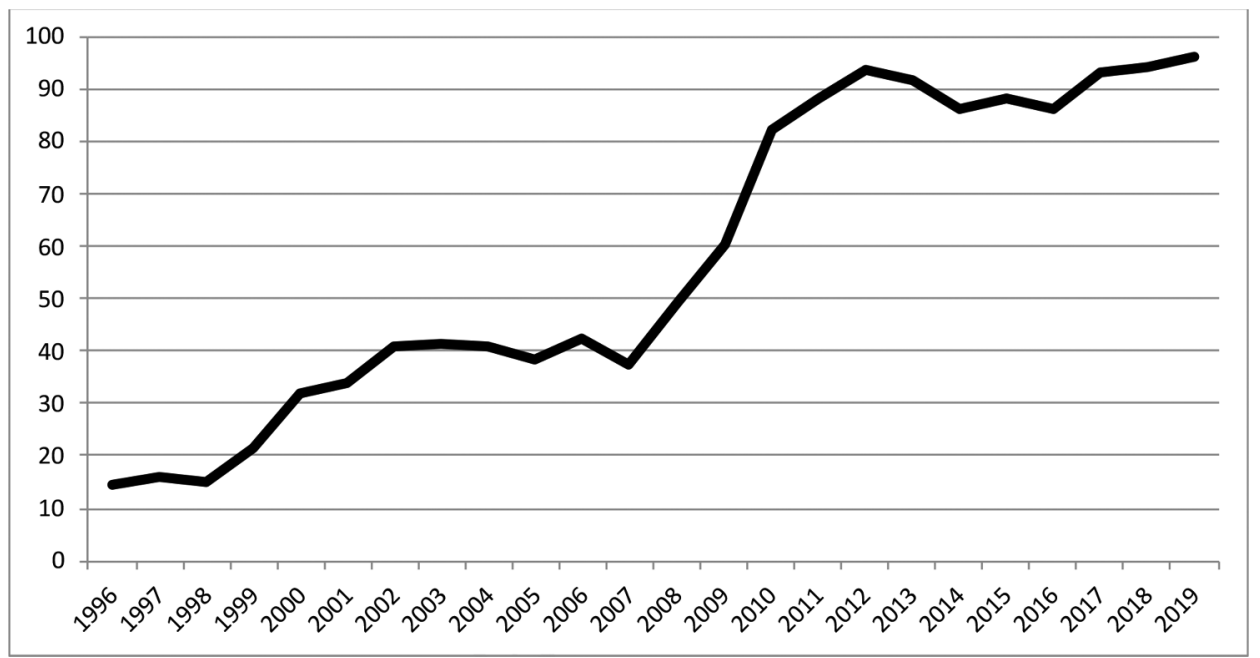

Figure 3. Proportion of EU legislative acts adopted with the co-decision procedure (since 2009: ordinary legislative procedure), 1996-2019.

subsequent trilogue phase that this dimension is taken into account. Once trilogues are organised, the initial equilibriums reached in the Council may move as the OLP fosters internal compromises.

Lastly, actors noted that the generalization of first-reading agreements is partly due to the fact that they do not entail a deadline - contrary to second and third readings - and therefore allow more time for negotiations. This factor might also foster intrainstitutional consensus.

\section{Number of legislative proposals}

We identified another type of institutional constraint in the progressive drop in the number of legislative proposals (see Figure 4). ${ }^{5}$

This trend, which began before Juncker's mandate and the Better Regulation agenda, might partly account for the enduring consensus within both legislative bodies. The Commission would put aside the most controversial drafts or focus on a limited number thereof, such as the migrant reallocation scheme. However, our interviews in the Council and the EP indicated that actors were generally unaware of this. The presidentialisation of the Commission may have had indirect effects on legislative activity, while the actors, embedded in day-to-day bargains, may have perceived these effects only to a limited extent. For instance, the president of the Commission's current ability to refuse some controversial drafts from his services, which is greater nowadays than that of ten years ago, has presumably contributed to circumscribing tensions within the Council (Kassim et al. 2017). However, such 'nondecisions' were hardly perceivable by legislative actors, as they did not consider them and still had to negotiate some controversial pieces that may have focused their attention. 
Table 5. OLP and intra-institutional consensus.

\begin{tabular}{|c|c|c|}
\hline & 2007-2008 & 2018 \\
\hline In the EP & $\begin{array}{l}\text { On this directive, you have what we always } \\
\text { organised [XXX: shadow rapporteur] and me: } \\
\text { a huge majority in the Parliament even in the } \\
\text { first reading. That's a clear signal to the Council. } \\
\text { Because the Council knew that there is } \\
\text { a qualified majority in the end, in the second } \\
\text { reading. So Parliament will win. That's why I did } \\
\text { not organise only a simple majority with the } \\
\text { liberals and that's why I invited the socialists as } \\
\text { well to come closer to follow. (I-2008-3) } \\
\text { Trilogues strengthen cohesion between us as } \\
\text { they give us the same interlocutor. We can play } \\
\text { with that institutional dimension to convince } \\
\text { hesitating colleagues. (I-2007-7) } \\
\text { For my report, I was blocked: EPP, Greens and } \\
\text { EUL were against. Therefore, I said that if we } \\
\text { did that, if nobody made a minimum of effort, } \\
\text { then it was all right for the Commission. And it } \\
\text { worked. (I-2007-8) }\end{array}$ & $\begin{array}{l}\text { When the Council sees that parliamentarians have } \\
\text { agreed on a motion of compromise, it is much } \\
\text { harder for them to resist it. So they should take } \\
\text { it into account. (I-2018-11) } \\
\text { If we want to be strong vis-à-vis the Council, we } \\
\text { should be united. It calls for the largest majority } \\
\text { within Parliament. And it is also true regarding } \\
\text { the Commission: discussions may be harsh with } \\
\text { the Council within trilogues but sometimes it is } \\
\text { even harsher with the Commission! (I-2018-9) }\end{array}$ \\
\hline In the Council & $\begin{array}{l}\text { The weight of the EP reinforces consensus within } \\
\text { the Council. We have to present a unified face } \\
\text { to the EP. The weight of the EP has increased } \\
\text { with the Directive on Services and REACH. [...]. } \\
\text { Before the trilogues, the Presidency asks } \\
\text { reluctant member states to make compromises; } \\
\text { it pushes member states towards consensus } \\
\text { before the trilogues. (I-2007-9) }\end{array}$ & $\begin{array}{l}\text { The EP involvement really weighs on the quest for } \\
\text { a compromise in the Council during the final } \\
\text { stage. Not at the beginning when the Council } \\
\text { defines its general position but after, when } \\
\text { trilogues start. [...] Sometimes, the majority } \\
\text { that was supportive of the Council's general } \\
\text { position crumbles or on the contrary is } \\
\text { strengthened as the Council should agree with } \\
\text { EP and that may impact the content of the } \\
\text { draft. (I-2018-10) } \\
\text { The EP is sometimes a good ally to cross out big } \\
\text { delegations and reach a good compromise. } \\
\text { (I-2018-1) }\end{array}$ \\
\hline
\end{tabular}

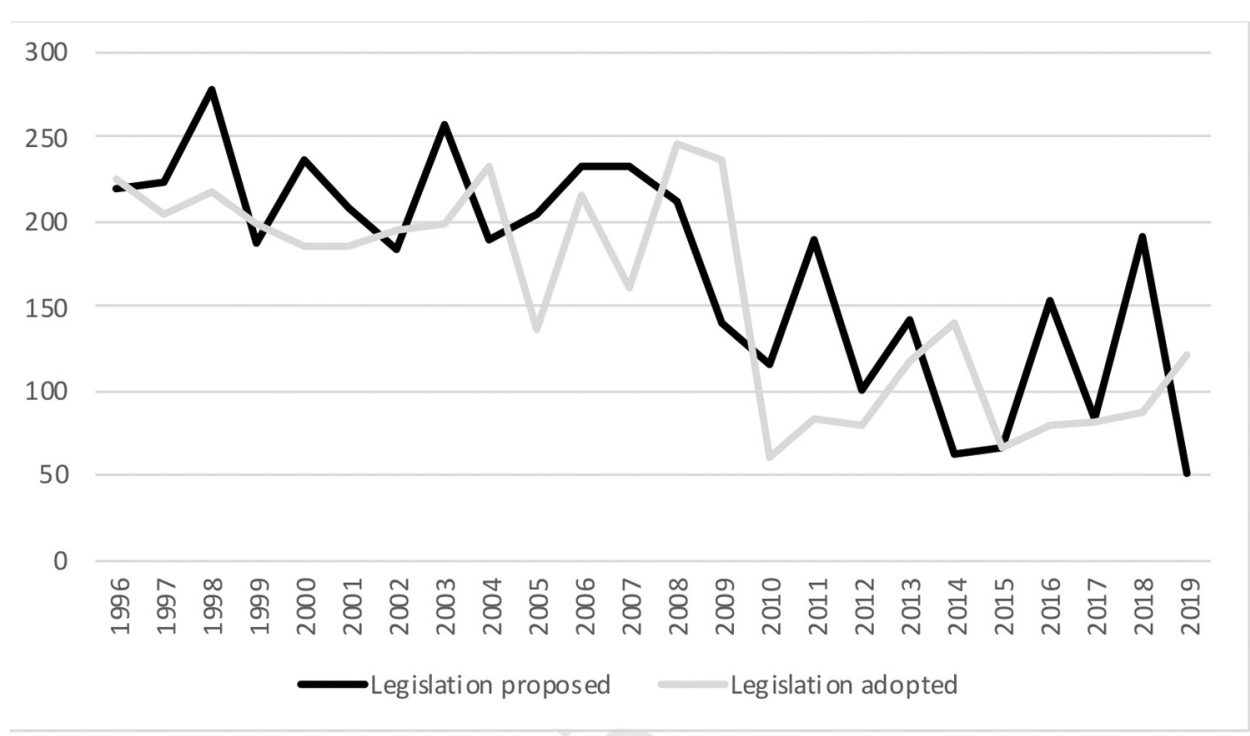

Figure 4. Legislative proposals. 1996-2019. 


\section{A pro-EU alliance}

Our last hypothesis is based on the paradoxical effect of the rise of Eurosceptic forces. The increasing electoral successes of anti-EU candidates would compel parties customarily opposed to each other to form closer-than-usual alliances, in order first to reach a majority, and second to send a message of unity. The greater saliency of the European issue within public opinion, what has been called the 'constraining dissensus' (Hooghe and Marks 2009), would lead those who do not share the Eurosceptic stance to form alliances.

There is little evidence for this explanation in the case of the Council because even antiEU governments rarely contest legislation. In 2018-2019, for instance, Hungary contested $8.5 \%$ of adopted acts, and Poland contested 6\%. Those rates are the highest in the EU, along with those of the UK (see Figure 1), the Czech Republic, Germany and Slovakia, but they remain limited given the diplomatic tensions between those two member states and EU institutions. Furthermore, we observed no systematic coalition of governments based on their ideological support for the principle of European integration. Coalitions are fluid and depend on the national, economic and sub-regional interests at stake, as well as traditional diplomatic alliances. Our data indicate that even the Visegrad group rarely opposes or abstains as a coalition. Figure 5 shows the size of coalitions of ministers opposing or abstaining on adopted acts in the Council. It shows the increasing prevalence of isolated contestation.

Except for a moderate increase in 2018, the proportion of cases in which more than two member states opposed or abstained on definitive legislative acts remained rather low throughout the period, despite the arrival of new countries, which is a strong point in favour of the continuity of behavioural norms within the Council.

Although little evidence for a pro-EU coalition can be found in the Council, the picture is different in the EP, as indicated in the recent literature. Otjes and van Der Veer (2016) showed that the Eurozone crisis led to a historical turn in the EP: although the primary cleavage was between the right and the left, and the secondary one occurred between

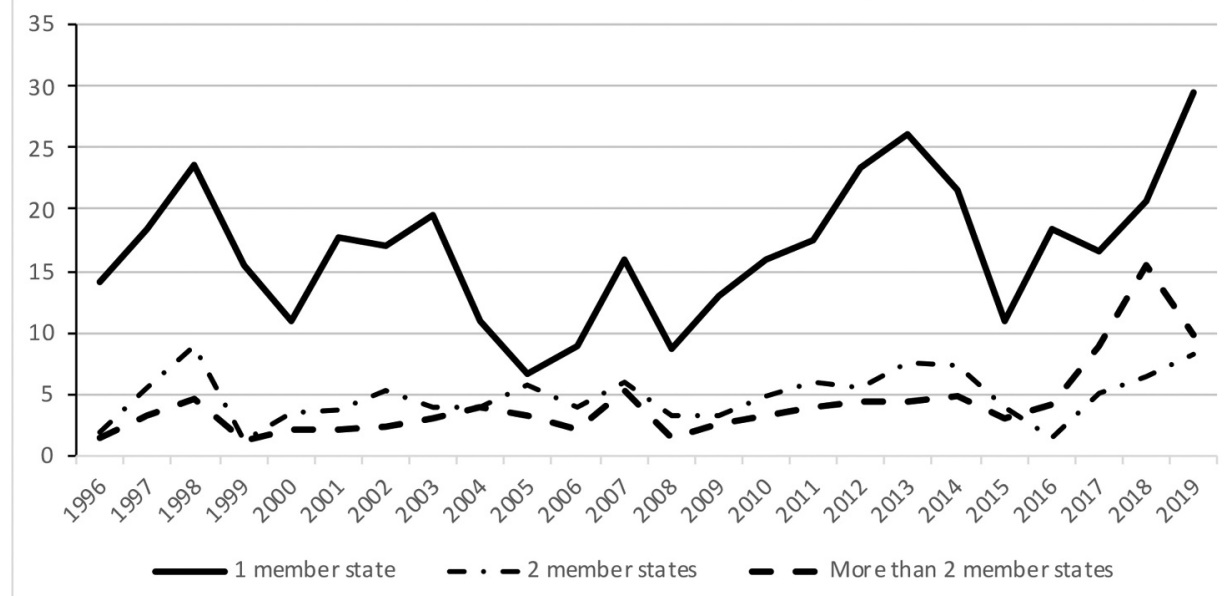

Figure 5. Size of the minority opposing or abstaining in the Council (\%), 1996-2019. 
the pro- and anti-integration camps, the latter dimension has become the dominant cleavage since 2009 (see also Braghiroli 2015; Roger, Otjes, and van der Veer 2017).

The 'crisis' legislative term of 2009-2014 was characterised by a noticeable reconciliation between the two main groups from the centre right and centre left (which represented more than half of the seats). Figure 6 shows that the proportion of convergent votes on the part of the European People's Party (EPP) and the Progressive Alliance of Socialists and Democrats (S\&D) was high and stable until 2014 and that between 2014 and 2019 , it became even higher, increasing to $80 \%$.

At the organizational level, the tendency of the pro-EU forces to form alliances against outliers is illustrated by the unprecedented 2015 decision to break with a solid tradition of proportional distribution of the positions within the assembly. The two dominant groups agreed that the newly-formed Europe of Nations and Freedom would be deprived of official positions. The closeness of the pro-EU forces under the 2014-2019 parliament also operated under the shadow of the 2019 European elections. As was said in a 2018 interview, 'If, in 2019, we have a lot of Eurosceptics, it will be more complicated. They are loose cannons.' (I-2018-12).

If our last explanation for the enduring consensus is confirmed in the case of the EP, recent interviews enable us to develop subtler observations. It seems that MEPs in charge of the negotiation process seek inclusiveness more systematically than they did ten years ago. Some interviewees told us that it is not rare, for example, to see a rapporteur seeking to convince Eurosceptic and radical right MEPs to join the final majorities. This evolution is explained by the slight erosion of the majority EPP and S\&D since the rise of Eurosceptic groups beginning in 2014 and also the spread of trilogues. MEPs mandated to negotiate the position of the EP in trilogues have to ensure a majority for each step of the procedure: adopting the negotiating mandate on behalf of the EP, adopting the agreement obtained

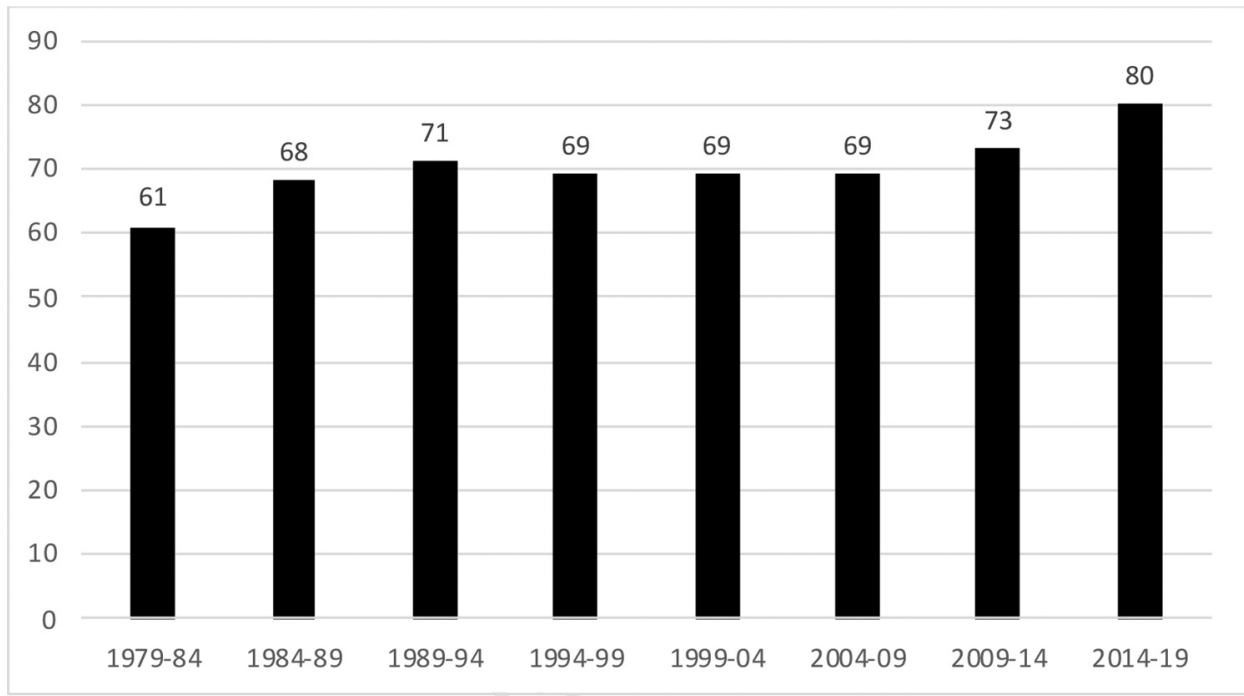

Figure 6. EPP and S\&D in the EP: Convergent votes (\%), 1979-2019. Source: Votewatch, https://www. votewatch.eu/ 
in trilogue in committee, and adopting it on the floor. Therefore, the risk that the majority could erode at each step of the process leads MEPs to seek more than a minimal winning coalition.

\section{Conclusion}

Our study shows how the EU legislative process unexpectedly accommodates the politicization of EU affairs. It gives relevance to the two theories traditionally adduced to explain consensus before 2009: commitment to the norm of consensus and the individual rational bias for cooperation. We argue that the resilience of consensus during the period 2009-2019 is due to the conjunction of these factors with new factors that reinforced existing trends: the generalization of the OLP and the fact that pro-EU MEPs sought to form alliances against anti-EU MEPs. Furthermore, the smaller number of legislative proposals made by the Commission is likely to foster consensus-building. These new factors allow us to further deconstruct what is often considered a cornerstone of the EU political system and show how diverse individual and institutional strategies combine to produce consensus. One could argue that smaller majorities within each legislative institution would enable the EU to show more ambition in some policy fields. Moreover, consensus entails costs in terms of accountability and transparency. However, the endurance of consensus despite the current polycleavage (Zeitlin, Nicoli, and Laffan 2019) seems to indicate that the EU is still far from the majoritarian avenue (Dehousse 1995). As in the period following to the major enlargement of 2004, consensus has persisted despite widespread expectations of a more conflictual legislative process. In addition to contributing to the understanding of the politicization of the EU political system or the lack thereof, our research shows that the EU legislative process is a fertile ground for neoinstitutionalist scholars and the study of norm resilience.

\section{Notes}

1. Centre de Données Socio-Politiques [dataset] (CDSP, CNRS-Sciences Po) and Centre d'Études Européennes (CEE, CNRS-Sciences Po) [productors], Centre de Données Socio-Politiques [distributor].Unless otherwise specified, we use this dataset.

2. We begin in 1996 because institutional archives for the period prior to 1996 are not available online. For the EP, we collected data until 05/31/2019; for the Council, we collected data until $12 / 31 / 2019$.

3. These statistics start in 2004 , as the EP does not provide with roll call votes for the period 1996-2004.

4. When we cite our interviews, we use the following referencing system: I-year-number. The interviews cited in the paper are listed in Appendix 1.

5. Source: https://ec.europa.eu/transparency/regdoc/?fuseaction=search, https://eur-lex. europa.eu/homepage.html, Häge 2011 and Schout and Schwieter (2018).

\section{Acknowledgement}

Our warm thanks go to the EU officials, national representatives and members of the European Parliament who agreed to be interviewed and to Renaud Dehousse. We are also grateful to the anonymous reviewers, Manuele Citi and Dimiter Toshkov for very helpful comments on earlier 
versions of this article.

\section{Disclosure statement}

No potential conflict of interest was reported by the authors.

\section{Funding}

This work was supported by the Agence Nationale de la Recherche (project ANR-12-BSH1-0012).

\section{ORCID}

Stéphanie Novak (D) http://orcid.org/0000-0001-5918-1836

Olivier Rozenberg (iD http://orcid.org/0000-0003-2468-7639

\section{References}

Benedetto, G. 2005. "Rapporteurs as Legislative Entrepreneurs: The Dynamics of the Codecision Procedure in Europe's Parliament." Journal of European Public Policy 12 (1): 67-88. doi:10.1080/ 1350176042000311916.

Börzel, T. A., and T. Risse. 2018. "From the Euro to the Schengen Crises: European Integration Theories, Politicization, and Identity Politics." Journal of European Public Policy 25 (1): 83-108. doi:10.1080/13501763.2017.1310281.

Brack, N. 2018. Opposing Europe in the European Parliament: Rebels and Radicals in the Chamber. London: Palgrave Macmillan.

Braghiroli, S. 2015. "An Emerging Divide? Assessing the Impact of the Euro Crisis on the Voting Alignments of the European Parliament." The Journal of Legislative Studies 21 (1): 96-114. doi:10.1080/13572334.2014.939559.

Brandsma, G. 2018. "Transparency of EU Informal Trilogues through Public Feedback in the European Parliament: Promise Unfulfilled." Journal of European Public Policy 26 (10): 1464-1483. doi:10.1080/13501763.2018.1528295.

Bressanelli, E., and N. Chelotti. 2018. "The European Parliament and Economic Governance: Explaining a Case of Limited Influence." The Journal of Legislative Studies 24 (1): 72-89. doi:10.1080/13572334.2018.1444627.

Burns, C. 2013. "Consensus and Compromise Become Ordinary-but at What Cost? A Critical Analysis of the Impact of the Changing Norms of Codecision upon European Parliament Committees." Journal of European Public Policy 20 (7): 988-1005. doi:10.1080/13501763.2013.795389.

Costa, O., and P. Magnette. 2003. "The European Union as A Consociation? A Methodological Assessment." West European Politics 26 (3): 1-18. doi:10.1080/01402380312331280568.

De Wilde, P., and M. Zürn. 2012. "Can the Politicization of European Integration Be Reversed?" JCMS: Journal of Common Market Studies 50 (s1): 137-153.

Dehousse, R. 1995. "Constitutional Reform in the European Community: Are There Alternatives to the Majoritarian Avenue?" West European Politics 18 (3): 118-136. doi:10.1080/ 01402389508425094.

Dinan, D., N. Nugent, and W. E. Paterson. 2017. The European Union in Crisis. London: Macmillan International Higher Education.

Elgström, O., and C. Jönsson. 2000. "Negotiation in the European Union: Bargaining or Problem-solving?" Journal of European Public Policy 7 (5): 684-704. doi:10.1080/ 13501760010014902.

Fabbrini, S. 2016. "From Consensus to Domination: The Intergovernmental Union in a Crisis Situation." Journal of European Integration 38 (5): 587-599. doi:10.1080/07036337.2016.1178256. 
Häge, F. M. 2011. “The European Union Policy-making Dataset." European Union Politics 12 (3): 455-477. doi:10.1177/1465116511398739.

Hayes-Renshaw, F., W. Van Aken, and H. Wallace. 2006. "When and Why the EU Council of Ministers Votes Explicitly." Journal of Common Market Studies 44 (1): 161-194. doi:10.1111/j.14685965.2006.00618.x.

Hix, S. 2014. "The EU as a New Political System." In Comparative Politics, edited by D. Caramani, 387-406. 3rd ed. Oxford: Oxford University Press.

Hix, S., Noury, A. G., and Roland, G. 2007. Democratic politics in the European Parliament. Cambridge, UK: Cambridge University Press. doi:10.1017/CBO9780511491955

Hooghe, L., and G. Marks. 2009. "A Postfunctionalist Theory of European Integration: From Permissive Consensus to Constraining Dissensus." British Journal of PoliticalScience 39 (1): 1-23. doi:10.1017/S0007123408000409.

Johnston, A. I. 2001. "Treating International Institutions as Social Environments." International Studies Quarterly 45 (4): 487-515. doi:10.1111/0020-8833.00212.

Juncker, J.-C. (2016). "Speech at the General Annual Meeting of the Hellenic Federation of Enterprises." Athens, 21 June. https://ec.europa.eu/commission/presscorner/detail/en/SPEECH_ 16_2293

Kassim, H., S. Connolly, R. Dehousse, O. Rozenberg, and S. Bendjaballah. 2017. “Managing the House: The Presidency, Agenda Control and Policy Activism in the European Commission." Journal of European Public Policy 24 (5): 653-674. doi:10.1080/13501763.2016.1154590.

Katz, R. S., and P. Mair. 1995. "Changing Models of Party Organization and Party Democracy: The Emergence of the Cartel Party." Party Politics 1 (1): 5-28. doi:10.1177/1354068895001001001.

König, T., and D. Junge. 2011. "Conflict Resolution in the Council by Linkage of Commission Proposals." In The 'Community Method', 76-88. London: Palgrave Macmillan.

Krehbiel, K. 1998. Pivotal Politics. A Theory of U.S. Lawmaking. Chicago: University of Chicago Press.

Kreppel, A. 1999. "What Affects the European Parliament's Legislative Influence? An Analysis of the Success of EP Amendments." Journal of Common Market Studies 37 (3): 521-537. doi:10.1111/ 1468-5965.00176.

Kreppel, A., and G. Tsebelis. 1999. "Coalition Formation in the European Parliament." Comparative Political Studies 32 (8): 933-966. doi:10.1177/0010414099032008002.

Laffan, B. 2004. "The EU and Its Institutions as Identity Builders." In Transnational Identities, Becoming European in the EU, edited by R. Herrmann, T. Risse, and M. Breuer, 75-96. Lanham, MD: Rowman \& Littlefield.

Lewis, J. 2003. "Institutional Environments and Everyday EU Decision Making: Rationalist or Constructivist?" Comparative Political Studies 36 (1-2): 97-124. doi:10.1177/ 0010414002239373.

Lewis, J. 2005. "The Janus Face of Brussels: Socialization and Everyday Decision Making in the European Union." International Organization 59 (4): 937-971. doi:10.1017/S0020818305050320.

Lord, C. 2003. "The European Parliament, Not a Very European Parliament?" Politique européenne 1: 30-48. doi:10.3917/poeu.009.0030.

Magone, J., B. Laffan, and C. Schweiger, eds. 2016. Core-Periphery Relations in the European Union: Power and Conflict in a Dualist Political Economy. Abingdon: Routledge.

Mattila, M., and J.-E. Lane. 2001. "Why Unanimity in the Council? A Roll Call Analysis of Council Voting." European Union Politics 2 (1): 31-52. doi:10.1177/1465116501002001002.

McKibben, H. E. 2010. "Issue characteristics, issue linkage, and states' choice of bargaining strategies in the European Union". Journal of European Public Policy 17 (5): 694-707. doi:10.1080/ 13501761003748682

Mühlböck, M., and B. Rittberger. 2015. "The Council, the European Parliament, and the Paradox of Inter-Institutional Cooperation." in: C. Neuhold and S. Vanhoonacker (eds): 'Dynamics of institutional cooperation in the European Union: Dimensions and effects' European Integration online Papers (EloP), Special issue 1, Vol. 19, Article 4, http://eiop.or.at/eiop/texte/2015-004a.htm, pp. 120.

Noury, A., and G. Roland. 2020. "Identity Politics and Populism in Europe." Annual Review of Political Science 23 (1): 421-439. doi:10.1146/annurev-polisci-050718-033542. 
Otjes, S., and H. van Der Veer. 2016. "The Eurozone Crisis and the European Parliament's Changing Lines of Conflict." European Union Politics 17 (2): 242-261. doi:10.1177/1465116515622567.

Puetter, U. 2014. The European Council and the Council: New Intergovernmentalism and Institutional Change. Oxford: Oxford University Press.

Reh, C., A. Héritier, E. Bressanelli, and C. Koop. 2013. "The Informal Politics of Legislation: Explaining Secluded Decision Making in the European Union." Comparative Political Studies 46 (9): 1112-1142. doi:10.1177/0010414011426415.

Ripoll Servent, A. 2018. The European Parliament. London: Palgrave McMillan.

Ripoll Servent, A., and L. Panning. 2019. "Eurosceptics in Trilogue Settings: Interest Formation and Contestation in the European Parliament." West European Politics 42 (4): 755-775. doi:10.1080/ 01402382.2019.1575639.

Roederer-Rynning, C., and J. Greenwood. 2015. "The Culture of Trilogues." Journal of European Public Policy 22 (8): 1148-1165. doi:10.1080/13501763.2014.992934.

Roger, L., S. Otjes, and H. van der Veer. 2017. "The Financial Crisis and the European Parliament: An Analysis of the Two-Pack Legislation." European Union Politics 18 (4): 560-580. doi:10.1177/ 1465116517716311.

Schout, J. A., and C. Schwieter. 2018. Two Decades of Better Regulation in the EU Commission: Towards Evidence-based Policymaking? Clingendael: Netherlands Institute of International Relations.

Settembri, P., and C. Neuhold. 2009. "Achieving Consensus through Committees: Does the European Parliament Manage?" JCMS: Journal of Common Market Studies 47 (1): 127-151.

Thomas, D. C. 2009. "Explaining the Negotiation of EU Foreign Policy: Normative Institutionalism and Alternative Approaches." International Politics 46 (4): 339-357. doi:10.1057/ip.2009.7.

Treib, O. 2020. "Euroscepticism Is Here to Stay: What Cleavage Theory Can Teach Us about the 2019 European Parliament Elections." Journal of European Public Policy 1-16. doi:10.1080/ 13501763.2020.1737881.

Whitaker, R. 2011. The European Parliament's Committees. National Party Influence and Legislative Empowerment. Abingdon-on-Thames: Routledge.

Wurzel, R. K., D. Liefferink, and M. Di Lullo. 2019. "The European Council, the Council and the Member States: Changing Environmental Leadership Dynamics in the European Union." Environmental Politics 28 (2): 248-270. doi:10.1080/09644016.2019.1549783.

Yordanova, N. 2013. Organising the European Parliament, the Role of Committees and Their Legislative Influence. Colchester: ECPR Press.

Zeitlin, J., F. Nicoli, and B. Laffan. 2019. "Introduction: The European Union beyond the Polycrisis? Integration and Politicization in an Age of Shifting Cleavages." Journal of European Public Policy 26 (7): 963-976. doi:10.1080/13501763.2019.1619803.

\section{Appendix 1. Interviews cited in the paper}

2007-1: Official, Council General Secretariat (CGS), 6 December 2007

2007-2: Official, CGS, 6 December 2007

2007-3: MEP, Czech Republic, Party of the European Socialist (PES), 13 February 2007

2007-4: Former deputy Permanent Representative of a big member state, 28 November 2007

2007-5: Official, Permanent Representation of a medium-size member state, 6 November 2007

2007-6: MEP, Germany, European People Party group (EPP), 23 February 2007

2007-7: MEP, Italy, EPP, 21 February 2007

2007-8: MEP, Hungary, PES, 15 February 2007

2007-9: Official, Permanent Representation of a big member state, 12October 2007

2008-1: Official, CGS, 17 January 2008

2008-2: MEP, Belgium, Alliance of Liberals and Democrats for Europe (ALDE), 16 July 2008

2008-3: MEP, Germany, EPP, 15 July 2008

2008-4: MEP, Greece, PES, 8 March 2008

2008-5: MEP, Spain, PES, 7 March 2008

2012-1: Official, Permanent Representation of a small member state, 5 November 2012 
2012-2: Official, Press Service, CGS, 13 November 2012

2016-1: Official, CGS, 16 June 2016

2017-1: MEP, Belgium, ALDE, 13 February 2017

2018-1: Official, Permanent Representation of a medium-size member state, 17 June 2018

2018-2: Official, Permanent Representation of a big member state, 17 June 2018

2018-3: Official, Permanent Representation of a small member state, 17 June 2018

2018-4: MEP, Italy, Greens/European Free Alliance, 12 February 2018

2018-5: MEP, France, EPP, 6 May 2018

2018-6: Official, CGS, 3 May 2018

2018-7: MEP, Italy, EPP, 6 June 2018

2018-8: MEP, France, EPP, 6 June 2018

2018-9: MEP, France, S\&D, 6 May 2018

2018-10: Official, CGS, 3 May 2018

2018-11: MEP, France, S\&D, 15 May 2018

2018-12: MEP, France, EPP, 25 May 2018 